\title{
Obituaries
}

\section{George Henry Reginald Curnock}

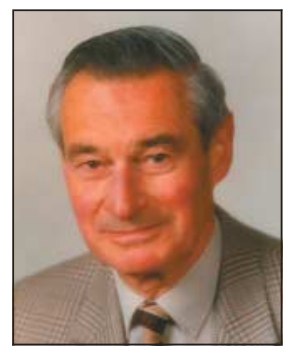

Former general practitioner Cheshunt, Hertfordshire (b 1918; q Charing Cross Hospital, London, 1942; FRCGP), died from prostate cancer on 16 May 2006.

Intending to qualify in dentistry and medicine and having completed a year of dentistry, George Henry Reginald Curnock ("Henry") switched to the more immediately useful clinical medicine when the second world war broke out. He served on HMS Cadmus, a minesweeper in the Mediterranean. After the war Henry worked in maternity and child welfare in East Ham. In 1950 he became a general practitioner in Cheshunt until retirement in 1981. He was a founder member of the Royal College of General Practitioners, being elected fellow in 1983 for integrating child and school clinics in East Hertfordshire with primary care teams. He worked part time until 1984 in school and infant welfare clinics in Welwyn Garden City. He leaves a wife, Vera; three sons; and seven grandchildren. [David Curnock]

\section{William ("Bill") George Edge}

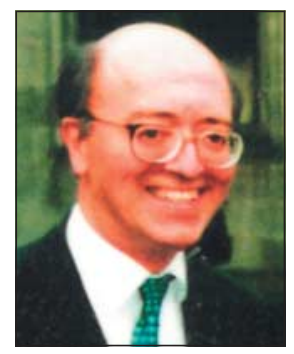

Former consultant anaesthetist Stoke Mandeville Hospital (b 1941; q Edinburgh 1966; FRCA), died shortly after a fall while on holiday in New Zealand on 9 March 2006.
Born in Lancashire, William ("Bill") trained in Edinburgh and at Hammersmith Hospital, and was appointed consultant at Stoke Mandeville Hospital in 1981. He enjoyed a wide range of practice, including anaesthetising patients with severe facial deformities, and was a respected teacher of nursing and junior staff. He retired owing to ill health in 2000. He later underwent a third neurosurgical operation, delighting in his improvement. He had a lifelong interest in cartography. He leaves a wife, Barbara; three children; and a granddaughter. [BARBARA EDGE]

\section{William ("Bill") Harding Helm}

Former consultant general and chest physician North Yorkshire (b 1918; q Middlesex Hospital, London, 1943; FRCP), died from cholestasis caused by flucloxacillin on 19 May 2006. A few months after qualifying, William Helm ("Bill") joined the Royal Army Medical Corps, serving during the attack on Caen in 1944. Later he served in Belgium and Holland, before working in military hospitals for two years in India. He developed an interest in chest medicine during stints at the Middlesex, London Chest, and Brompton Hospitals before becoming consultant in Burnley in 1955. In 1960 he became senior consultant in York, helping to develop chest services across much of North Yorkshire. He was president of the Yorkshire Thoracic Society and the York Medical Society, and after retiring in 1981 researched into tuberculosis in the Bronte family. He leaves a wife, Diana; four children; and six grandchildren. [Тову HeLm]

\section{John George Macleod}

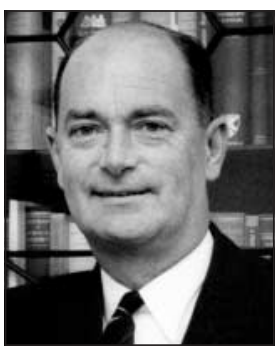

Former consultant physician Western General Hospital, Edinburgh (b 1915; q Edinburgh 1938; FRCP Ed), died from bronchopneumonia on 4 April 2006.
In 1950 John Macleod was appointed physician at the Western General Hospital, Edinburgh, one of a cadre of talented young clinicians recruited by Sir Stanley Davidson. His inspirational teaching of clinical medicine formed the basis of his popular multiauthor textbook Clinical Examination, now in its 11th edition, having sold some half a million copies. In 1964 Sir Stanley Davidson entrusted him with the editorship of Davidson's Principles and Practice of Medicine, which has sold over two million copies. John edited six editions. In $1971 \mathrm{John}$ was elected for the following six years as the second chairman of the University Department of Medicine at the Western General Hospital-a rare achievement. Predeceased by his wife, Nancie Elizabeth, in 1995, he leaves three children. [MARTIN EASTwOOD, Michael Matthews]

\section{John Joseph Mould}

Consultant clinical oncologist Queen Elizabeth Hospital, Birmingham 1982-2001 (b 1944; q Royal Free Hospital, London, 1969; MRCOG, FRCR), died from pancreatic cancer on 8 March 2006.

After house jobs in London John initially explored a career in gynaecology before combining this specialty with clinical oncology. His specialist training was obtained at the Christie Hospital, Manchester, before he joined the staff of the Queen Elizabeth Hospital in 1982. In 2001 his took early retirement, enjoying the Poole countryside. [DAVID SPOONER]

\section{Advice}

We will be pleased to receive obituary notices of around 250 words. Pressure on space means that in most cases we will be able to publish only about 100 words in the printed journal, but we can run a fuller version on our website. We will take responsibility for shortening. We do not send proofs. Good quality, original photographs are welcome. Please give a contact telephone number and, where possible, supply the obituary on a disk or byemail to obituaries@bmj.com If sending a picture electronically, please attach as a jpeg or a tiff rather than as part of a Word document. We need to know the year of birth and exact date of death of the deceased, and we prefer obituaries to state the cause of death. Please spell out abbreviations. 


\section{Trevor Peter Oldham}

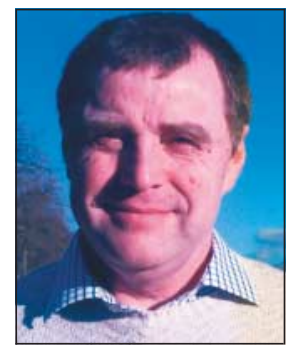

Former general practitioner Denbigh, North Wales (b 1953; q Birmingham 1976; MRCP, AFOM, MSc), died from a heart attack on 6 June 2006.

After qualifying Trevor became an army medical officer in Minden, West Germany, Northern Ireland, Canada, and Hong Kong, transferring to the Military Hospital in Aldershot in 1982. After leaving the army he entered general practice, moving to Cumbria in 1994, where he pursued his outdoor interests and became a member of the Furness Mountain Rescue team. In 1997 he developed heart failure after myocarditis. Although eventually able to return to work, he changed career to occupational medicine. However, missing daily patient contact, he returned to group practice in Denbigh, North Wales, in 2003. His heart failure increased dramatically in 2005, though he continued to live life to the full. He leaves a wife, Heather; two children; two stepchildren; and four grandchildren. [HEATHER Oldham]

\section{Ernest Philip Quibell}

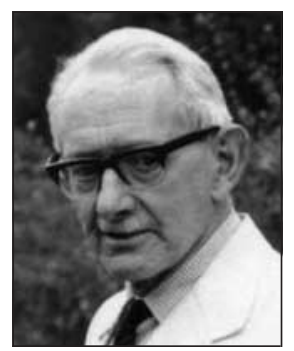

Former medical director and consultant paediatrician Chailey Heritage Craft School and Hospital, Sussex (b 1910; q St

Bartholomew's Hospital, London 1937; DCH, OBE), died from a stroke on 3 July 2006.

Ernest Philip Quibell ("Philip") became interested in paediatric rehabilitation at Lord Mayor Treloar Hospital School before the second world war. After war service in the Welsh Guards and further training, he was appointed medical administrator at Chailey Heritage Craft School and Hospital in 1950 . He was a pioneer in managing severe paediatric disability resulting from the polio epidemic in the early 1950s and later thalidomide. In the 1970 s and ' 80 s he cared for many children with spina bifida and hydrocephalus. After retiring in 1975 Philip worked with the Thalidomide Trust, being awarded the OBE in 1976. Predeceased by his first wife, Edmee, and his eldest son, he leaves a second wife, Doreen; two children; and nine grandchildren. [GILLIAN T MCGarthY]

\section{Neville Wilson Shephard}

Former managing and research director Medical Science Research, Aylesbury (b 1929; q Sheffield 1953), died from a heart attack on 3 January 2006.

Neville worked at Sheffield University hospitals and then in the Royal Air Force before entering general practice, becoming senior partner. In 1963 he joined Ortho Pharmaceuticals as medical and research director, moving to Roussel Laboratories in 1974. From 1977 to 1996 he ran his own research company, MSR (Medical Science Research), based in Buckinghamshire. After retirement he cultivated his artistic talents (drawing and pastels) and playing the piano, and he had a keen interest in horse racing. Predeceased by his first wife and only son, he is survived by his second wife, Pam; two daughters; and two grandchildren. [РАM SHEPHARD]

\section{Colin Starkie}

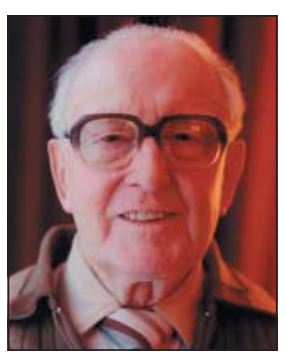

Former medical officer of health Kidderminster and deputy county medical officer of health Worcester (b 1908; q Manchester 1932; MD, DPH), 223 July 2006.

Colin Starkie became deputy medical officer of health in Hyde, Cheshire, and served in the second world war as a major in the Royal Army Medical Corps in Africa, Italy, and Austria. He was appointed medical officer of health in Kidderminster in 1947. He identified smoking as the important cause of lung cancer and spoke vehemently against smoking. He worked with Gerald Nabarro MP on the introduction of the Clean Air Bill in 1956. After his retirement in his early 1970 s he continued with his main hobby, which was woodwork. He leaves a wife, Joy, and two daughters and their families. [CAROL StARKIE]

\section{Gladys Elsa McArthur Strang (Mrs Scarlett)}

Former consultant psychiatrist High Croft Hospital, Birmingham (b 1913; q St Andrews 1937; MRCPsych), died from metastatic renal carcinoma on 18 January 2006.

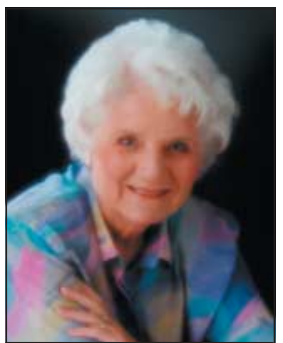

Gladys went to St Andrews University to read French philosophy and psychology but soon switched to medicine. After house jobs in Birmingham she married Rex, an ear, nose, and throat consultant, and worked in family planning, general practice, and public health for over 20 years. In her late 50 s she changed career and, aged 60 , was appointed consultant psychiatrist at High Croft Hospital, working in psychiatry until the age of 84 At the age of 86 and after 29 years of widowhood Gladys married Henry Scarlett CBE (aged 90), attracting national media coverage and debate. She leaves four children and 13 grandchildren. Henry died 12 days after her. [Fiona Kingston]

\section{Helen Holme Tucker (née Barwise)}

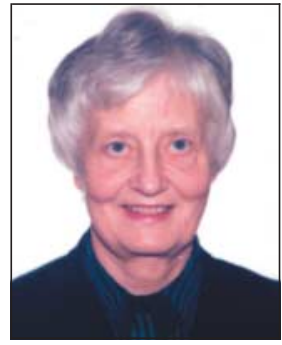

Former senior clinical medical officer in gynaecology North Staffordshire Royal Infirmary (b 1943; q Royal Free Hospital, London, 1967; FFFP), died from colorectal cancer on 16 June 2006.

After time out of medicine to look after her three children, Helen returned to clinical practice as a research fellow in cardiology, publishing a paper in the $B M J$ advocating the early mobilisation and discharge of patients after myocardial infarction. After funding for her post was withdrawn, Helen eventually became clinical medical officer in child health/immunisation and gynaecology. On promotion to senior clinical medical officer she worked entirely in gynaecology and was lecturer in the postgraduate department of obstetrics and gynaecology at Keele University. Shortly afterwards she became joint regional adviser for family planning in the Midlands. She retired in 2001. She leaves a husband, John; three children; and four grandchildren. [Simon Tucker]

Longer versions of these obituaries are available on bmj.com 